Does organic supply growth lead to reduced price premiums? The case of salmonids in Denmark

Ankamah-Yeboah, Isaac; Nielsen, Max; Nielsen, Rasmus

Published in:

Marine Resource Economics

DOI:

$10.1086 / 703087$

Publication date:

2019

Document version

Peer reviewed version

Citation for published version (APA):

Ankamah-Yeboah, I., Nielsen, M., \& Nielsen, R. (2019). Does organic supply growth lead to reduced price premiums? The case of salmonids in Denmark. Marine Resource Economics, 34(2), 105-121.

https://doi.org/10.1086/703087 


\title{
Does organic supply growth leads to reduced price premiums? The case of salmonids in Denmark $^{1}$
}

Isaac Ankamah-Yeboah*, Max Nielsen and Rasmus Nielsen

Institute of Food and Resource Economics, Faculty of Science, Rolighedsvej 25, 1958

Frederiksberg C, Denmark

*Corresponding Author: Tel: +4535333755

E-mail addresses: iay@ifro.ku.dk (I. Ankamah-Yeboah), max@ifro.ku.dk (M. Nielsen),rn@ifro.ku.dk (R. Nielsen).

\begin{abstract}
.
Consumers buy organic products to increase utility, while farmers invest in organic production to achieve price premiums. However, investors would like to avoid the risk of falling prices when organic supply increases to maintain profit. We suggest the use of market integration tests between non-stationary price series of organic/conventional products to reveal whether increasing organic supply can be expected to reduce price premiums. Increased organic supply will induce price falls if organic/conventional markets are independent. Organic supply growth will leave price premiums unchanged, if prices move together over time, since conventional supply typically is larger than organic. The method is applied to the Danish market for farmed salmonids. Cointegration is identified up- and down-stream, while the Law of One Price only holds upstream in the long run. Upstream, conventional trout is market leader, while impulse-response functions identify significant short run responses from conventional to organic trout prices, but not vice versa. Downstream, market leaders cannot be identified, nevertheless impulse-response analysis show significant short run responses from conventional to organic salmonid prices, however, no significance is detected in the opposite direction. The result indicates that organic salmonid prices are tied to the conventional market and do not develop independently. Hence, it can be expected that price premiums are maintained when investing in organic salmonid farming.
\end{abstract}

Keywords: Organic salmonids, Price Premium, Investment, Market Integration, Cointegration, Law of One Price, Impulse-response Function.

JEL Classification Codes: L11, Q21, Q22.

\section{Introduction}

Increasing demand for organic products has led to a growing number of farmers considering converting from conventional to organic production. This also increases the demand for more knowledge on price development of organic products to avoid the risk of weakened prices when investing in organic farming. In the literature, the focus have mainly been on identifying the price

1 Acknowledgement: This work is part of RobustFish. RobustFish is part of the Organic RDD 2 programme, which is coordinated by International Centre for Research in Organic Food Systems (ICROFS). It has received grants from the Green Growth and Development programme (GUDP) under the Danish Ministry of Food, Agriculture and Fisheries. 
premium of organic products and less on whether this price premium can be expected to be maintained. If high price premiums are received, more producers can convert to organic production and increasing organic supplies could, ceteris paribus, induce a downward pressure on prices. The purpose of this article is to show how market integration test of non-stationary price series of organic/conventional products can be applied to reveal important information on the riskiness of investments in organic farming and to apply the methodology on farmed salmonids (salmon and trout) in Denmark.

A Vector Auto Regressive Model in Error Correction Form is estimated for nonstationary price series. Cointegration between organic/conventional price series identifies long run market integration and the Law of One Price (LOP) show perfect market integration. Weak exogeneity tests reveal whether conventional prices lead organic prices, while impulse-response functions inform about the short-run adjustment process and time horizon following price shocks.

The issue of market integration between organic/conventional products is important when investing in organic farming, because risk of price reductions induced by growth in organic supply is normally only identified ex post, not ex ante. Hence, if organic price reductions are expected, this should be taken into account by the investor to insure an economic viable business when converting to organic production. Testing before the initial investment is made can identify the possible risk following from growth in organic supply. However, risks at the total market for conventional and organic products remains where prices are determined by total supply and demand.

Organic products face a constant price premium above conventional products when markets are integrated, since the prices of conventional/organic products follow each other during the adjustment period. The relevance of identifying this constant price premium depends on the market share of organic products. When the organic market share is small and markets are integrated, the method provides important information on stability of price premiums, with the implication that organic supply growth has limited effect on organic prices. However, when the organic market share is large and markets are integrated organic supply growth induces price reductions for organic products even though price premiums are stable. If markets are not integrated, a price reduction often follows growth in supply of organic products.

Several studies identify price premiums of organic food products using a hedonic price model, including Maguire, Owans and Simon (2004) on baby-food in two cities in California and North Carolina, Corsi and Strøm (2013) on farm-gate prices on wine in Piedmond, Italy, and AnkamahYeboah, Nielsen and Nielsen (2016) on salmon in Danish retail sale. Connolly and Klaiber (2014) identified heterogeneous price premia for various organic certifications across states in the US. Other authors have identified price premiums on labelled/certified products praising specific social/environmental friendly attributes, such as, Fair Trade coffee in Sweden (Schollenberg 2010) and on Marine Stewardship Council eco-labelled wild-caught seafood in the UK (Roheim, Asche and Santos 2011). Choice experiments are used to identify the organic price premiums, for example in Van Loo (2011) for chicken breast in Arkansas. Ankamah-Yeboah et al (work in progress) identified significant marginal willingness to pay for organic trout over conventional and competing Aquaculture Stewardship Council certified products among German consumers. Meas et al (2014) also identified a positive willingness to pay for organic blackberry jam and a strong substitution effects between local and organic production claims. 
Market integration tests of non-stationary price series have been used to identify the market within which prices move together over time. The use is widespread between fish species, since the global seafood markets are diversified with a large number of species supplied. Contributions include Asche, Bremnes and Wessels (1999) studying market integration between domestic wildcaught salmon and farmed imported salmon in the US, Ankamah-Yeboah, Staahl and Nielsen (forthcoming) between warm-water shrimp and cold-water shrimp, respectively in five European countries, and Bronnmann, Ankamah-Yeboah and Nielsen (2016) between different wild-caught and farmed whitefish species in Germany.

Studies of market integration between organic and conventional products are sparse. Singerman, Lence and Kimble-Evans (2014) identify market integration between states in the US for conventional corn and soy bean, and loose market integration at the corresponding organic markets. Market integration across organic and conventional markets could, however, not be found. Würriehausen, Ihle and Lakner (2015) also test for market integration and finds that the extent to which the organic price depends on the conventional price differs over time.

Our article tests for market integration between organic and conventional products. To the best of our knowledge, it is the first that find stable price premium of organic products over time and to suggest that this could actually be used as a risk reducing tool when used as a pretest before investment. The article furthermore adds to the literature by using impulse-response functions in the analysis to show the dynamic adjustment processes in the short-run following price shocks.

The article is organized as follows. In section two, the Danish market for salmonids is described. Section three present the methodology, while section four goes through data. Results are presented and discussed in section five and the last section concludes the article.

\section{The Danish Market for Salmonids}

The beginning of the modern and intensive fish farming was first introduced by a German farmer in 1741 (Jacobi, 1765). He successfully fertilized trout eggs and raised the fish that hatched. Today, the control of the life cycle from the fertilization of the eggs to a full grown fish is recognized to be the main driver of growth in productivity and thereby production volume (Anderson, 2002; Asche, 2008; Asche et al. 2013). The knowledge on salmonid production was reintroduced and spread throughout Europe in the 1840s, including Denmark (Hessel 1993).

Despite the established importance of seafood as a nutritious source of protein and other health benefits (Daviglus et al., 2002; Brunsø et al., 2008), there has been growing concerns about the sustainability of the aquaculture sector (Asche et al., 2015; Asche \& Bjorndal, 2011, Nielsen 2012, Nielsen et al. 2014). Thus, the use of information, such as eco-labelling forms an alternative way of regulating environmental externalities. Eco-labelling differentiates products by making the production method (organic/conventional) visible to consumers. Most often, the organic production process is more costly and producers undertaking these methods therefore expect higher prices than received when producing conventional. Trout and salmon producers in Europe have the opportunity to certify their product through different private and governmental organic labelling schemes. In Denmark, farmed fish are 
certified with the well-established and well-known organic label, a red $\varnothing$ (Christensen et al., 2014), which is issued, enforced and controlled by the Danish government.

The Danish market for rainbow trout (Oncorhynchus mykiss) produced in fresh water is mainly covered by domestic production. In 2014, the production reached 30,500 tons produced in 177 farms of which 9 farms where producing organic reaching a volume of 843 tons. The fish weigh less than 0.5 kilo each, have white meat and is not considered a substitute for salmon (Nielsen et al. 2007). In Denmark, a handful of processing companies dominate the market buying up fish from farmers. The main product forms are fresh/frozen whole fish and smoked fillets. More than $90 \%$ of the Danish production is exported, primarily to Germany. The total supply at the European market is 290 thousand tons, where Denmark delivers 11\% (FAO 2016). Table 1 is showing the most important producer countries of organic trout and salmon in Europe, and mention the share of organic production to total volume. The share of organic produced trout in Denmark was $2.8 \%$ of the total production, which seems equivalent to the level in France and Germany.

Table 1 Organic and conventional produced trout and salmon, 2014

\begin{tabular}{lrrr}
\hline $\mathbf{2 0 1 4}$ & $\begin{array}{r}\text { Organic production } \\
\text { tons }\end{array}$ & $\begin{array}{r}\text { Total production } \\
\text { Tons }\end{array}$ & $\begin{array}{r}\text { Share of organic } \\
\text { production (\%) }\end{array}$ \\
\hline Trout (fresh water) & & & \\
Denmark & 843 & 30,452 & 2.8 \\
France & App. 700 & 34,000 & 2.1 \\
Germany & App. 300 & 9,937 & 3.0 \\
\hline Total Trout (ton) & $\mathbf{1 , 8 4 3}$ & $\mathbf{7 4 , 3 8 9}$ & $\mathbf{2 . 5}$ \\
\hline & & & \\
Salmon (marine) & & & 1.3 \\
Norway & App. 16,000 & $1,258,356$ & 2.0 \\
UK & 3,588 & 179,022 & 84.0 \\
Ireland & 7,869 & 9,368 & $\mathbf{1 . 9}$ \\
\hline Total salmon (ton) & $\mathbf{2 7 , 4 5 7}$ & $\mathbf{1 , 4 4 6 , 7 4 6}$ &
\end{tabular}

Sources: FAO 2016 and Statistics Denmark 2016,

https://www.destatis.de/DE/Publikationen/Thematisch/LandForstwirtschaft/Fischerei/Aquakulturbetriebe

The Danish production of conventional salmon is negligible reaching less than 500 tons. The Danish market for salmon is dominated by imports from Norway and UK who is the leading producers in Europe. The most important product sold is whole fresh salmon. Denmark is an intermediate market and most of the salmon is re-exported to other EU countries. The global production of Atlantic salmon (Salmo salar) reached 2.3 million ton in 2014. It is estimated that the European production of organic salmon reached 27,500 ton in 2014 originating from Norway, UK and Ireland. In Ireland, the total production of salmon has been converted from conventional to organic production in 2015 due to the more favourable prices on organic products. 
Denmark has the highest share of organic food products sold in retail in the world covering $7.6 \%$ of the total sale of food and beverages, in 2014. In table 2, the production of different organic food product and their shares of total production are shown. Furthermore, the share of organic food products in different food categories in Danish retail is shown.

Table $2 \quad$ Organic food products share of total production in Denmark, 2014

\begin{tabular}{|c|c|c|c|c|c|}
\hline $\begin{array}{l}\text { Production } \\
\text { in ton }\end{array}$ & $\begin{array}{r}\text { Fresh water } \\
\text { trout }\end{array}$ & $\begin{array}{l}\text { Pork } \\
\text { meat }\end{array}$ & Milk & Eggs & \\
\hline Total & 30,452 & $1,944,000$ & $5.191,100$ & 68,905 & \\
\hline Organic & 843 & 9,020 & 479,700 & 12,256 & \\
\hline $\begin{array}{l}\text { Organic share } \\
\%\end{array}$ & 2.8 & 0.5 & 9.2 & 17.8 & \\
\hline Retail sale & $\begin{array}{l}\text { Fish and } \\
\text { shellfish }\end{array}$ & Meat & $\begin{array}{r}\text { Dairy } \\
\text { products }\end{array}$ & Eggs & $\begin{array}{r}\text { All food and } \\
\text { beverages }\end{array}$ \\
\hline $\begin{array}{l}\text { Organic share } \\
\%\end{array}$ & $1.0 \%$ & $4.2 \%$ & $4.0 \%$ & $0.4 \%$ & $7.6 \%$ \\
\hline
\end{tabular}

Sources: Statistics Denmark 2012 and 2016a

Compared to other products, milk and eggs, the primary production of organic fish only constitutes a small share of the total market. The production of organic milk and eggs are well established on the Danish market and they have been able to maintain a price premium for over 20 years even though the market share has increased. Looking at the retail sale, the organic sale of fish and shellfish only constitute $1 \%$, where meat and dairy products have a market share of $4 \%$. Thus, there is no indication that the production of organic fish has reached a volume that will significantly affect price premiums.

Denmark is the most expensive country in the European Union when it comes to purchasing food (Statistics Denmark 2016b). In spite of this, a large segment of consumers are willing to purchase organic products with even higher prices and the increasing development in the purchase of organic products is expected to continue in the coming years, reaching $8.5 \%$ of the total sale of food and beverages in 2015 .

\section{Methodology}

Commodity prices are seen by economists as valuable information medium for drawing relationships among commodity markets. Per earlier market definitions (Cournot, 1971 and Stigler and Sherwin, 1985), market integration have been founded on the test of the Law of One Price (LOP) where the price relationship between two markets is simply expressed as the long run relation

$p_{t}^{1}=a+\beta p_{t}^{2}+e_{t}$

where $p_{t}$ is a price vector (in this case organic and conventional prices), $e_{t}$ is the error term and $a$ (measures quality differences/premium) and $\beta$ are unknown parameters to be 
estimated. A test of the LOP is implemented by imposing the restriction $\beta=1$. A rejection of the LOP implies partial market integration while failing to reject implies perfect market integration, implying that relative prices are constant (Asche, Bremnes and Wessells, 2001). In the case of partial market integration, organic prices could fluctuate above the conventional with a premium. Despite the simplicity of equation 1, estimation is not that straight forward as one has to consider the dynamic patterns to reflect delayed adjustments to costs and the nonstationary time series properties of the series. As shown by (Granger and Newbold, 1974), estimating equation 1 on nonstationary variables renders normal statistical inference invalid due to spurious regression.

In order to determine what kind of model to estimate, the study first examines the stationary properties of the price series. Here, the standard Augmented Dickey Fuller (ADF) unit root test of Dickey and Fuller (1979) is considered alongside with a post-estimation approach indicated in Hjalmarsson and Österholm (2010). The post-estimation is considered for checkup because the ADF type models are quite often sensitive to the lags specified. In the presence of unit root, cointegration becomes the natural analysis to consider. Cointegration of variables $p_{t}=\left(p_{t}^{\text {organic }}, p_{t}^{\text {conventional }}\right)$ implies defining equilibrium relation such that, there exists a vector $\beta$ that renders the combination, $\beta^{\prime} p_{t}$, a stationary process.

In this study, we consider the Johansen (1988) cointegration over the two stage estimation procedure of Engle and Granger (1987) given our interest in testing the proportionality between prices. The Engle and Granger approach do not provide well-defined limiting distributions for direct test on the $\beta$ coefficient in equation 1 . The Johansen (1988) cointegration is a maximum likelihood estimation of the vector autoregression model (assuming order 1)

$\Delta p_{t}=\delta+\Gamma \Delta p_{t-1}+\Pi p_{t-1}+\epsilon_{t}$

Again, $p_{t}$ is $n \times 1$ vector of endogenous price variables; $\Gamma$ is $n \times n$ matrices of short run parameters; $\Pi$ is $n \times n$ matrix of long-run parameters; $\delta$ captures deterministic terms and $\epsilon_{t}$ is a vector of errors assumed to be independent and identically distributed. If $\Pi=\alpha \beta^{\prime}$ of rank ( $\mathrm{r}$ ), $0<r<n$, then the system can be said to be cointegrated. The parameters $\alpha$ and $\beta$ are matrices of dimension $n \times r$ with $\beta$ representing cointegrating vectors while $\alpha$ gives the weight of the cointegration relationships. Johansen (1988) proposes two test statistics for testing the cointegration rank, namely the trace and maximum eigenvalue statistics. Cheung and Lai (1993) and Gonzalo (1994) indicate that, Johansen's trace and maximum eigenvalue test for cointegration are robust to non-normal errors. Non-normal errors are often empirical challenge and so the Johansen cointegration presents further advantage for its use.

In this study, we estimate a bivariate model for organic and conventional rainbow trout at the farm level and a trivariate system for organic salmon and conventional salmon and trout at the retail level. Writing out the system of equations, we can represent the vector error correction model (VECM) with one cointegrating equation for the bivariate system at the farm level as 
$\left(\begin{array}{l}\Delta p_{t}^{1} \\ \Delta p_{t}^{2}\end{array}\right)=\left(\begin{array}{l}\delta_{1} \\ \delta_{2}\end{array}\right)+\left(\begin{array}{ll}\Gamma_{11} & \Gamma_{12} \\ \Gamma_{21} & \Gamma_{22}\end{array}\right)\left(\begin{array}{l}\Delta p_{t-1}^{1} \\ \Delta p_{t-1}^{2}\end{array}\right)+\left(\begin{array}{l}\alpha_{1} \\ \alpha_{2}\end{array}\right)\left(p_{t-1}^{1}-\beta p_{t-1}^{2}\right)+\begin{aligned} & \epsilon_{t}^{1} \\ & \epsilon_{t}^{2}\end{aligned}$

and the trivariate retail level system with two cointegrating equations as

$\left(\begin{array}{l}\Delta p_{t}^{1} \\ \Delta p_{t}^{2} \\ \Delta p_{t}^{3}\end{array}\right)=\left(\begin{array}{l}\delta_{1} \\ \delta_{2} \\ \delta_{3}\end{array}\right)+\left(\begin{array}{ll}\Gamma_{11} & \Gamma_{12} \\ \Gamma_{21} & \Gamma_{22} \\ \Gamma_{31} & \Gamma_{32}\end{array}\right)\left(\begin{array}{l}\Delta p_{t-1}^{1} \\ \Delta p_{t-1}^{2} \\ \Delta p_{t-1}^{3}\end{array}\right)+\left(\begin{array}{ll}\alpha_{11} & \alpha_{12} \\ \alpha_{21} & \alpha_{22} \\ \alpha_{31} & \alpha_{32}\end{array}\right)\left(\begin{array}{l}p_{t-1}^{1}-\beta_{13} p_{t-1}^{3} \\ p_{t-1}^{2}-\beta_{23} p_{t-1}^{3}\end{array}\right)+\begin{array}{r}\epsilon_{t}^{1} \\ \epsilon_{t}^{2} \\ \epsilon_{t}^{3}\end{array}$

with the following restrictions imposed in equation 4 to enable identification: $\beta_{11}=\beta_{22}=$ 1 and $\beta_{12}=\beta_{21}=0$. Variables and parameters are defined as before. The existence of cointegration does not in itself show which markets equilibrium adjust or do not; neither does it entail which adjusts fast or slow. Such information is provided by the $\alpha$ parameters (known as the speed of adjustment parameter). Weak exogeneity of prices which is used to identify leading markets in the system is tested by $\alpha_{i j}=\alpha_{i k}=0, \forall j \neq k$. The existence of a long run cointegration relationship implies that at least one of the $\alpha^{\prime} s$ is statistically different from zero. How to impose restrictions for the test of LOP is detailed later in the results section.

The post-estimation unit root raised earlier is implemented by imposing further restrictions on the cointegrating vectors. In this way, one is able to certainly conclude whether the evidence of cointegration is driven by a unit root process ${ }^{2}$.

While the VECM is used to assess the long run equilibrium between the market prices, the short-run dynamics is assessed by considering the impulse response functions (IRF). The IRFs show how each of the variables respond to an exogenous shock to the system. Thus, it reveals the evolution of market prices along a specified time horizon following an exogenous shock to the system. In the case of a cointegrated system, computation of IRFs from a Moving Average Representation (MA) of the VECM presents much more precise estimates (Lutkepohl, 2005).

\section{Data}

To investigate the linkages between ecological and conventional fish markets, we use data for two fish products; trout and salmon. We use two sets of data, a farm level trout prices that spans from May 2010 to September 2015 and is obtained from a parent company with three production units accounting for approximately 48 percent of total organic trout production in Denmark. The second set of data is obtained from GfK consumer panel and represents retail market prices. The panel contains records of Danish households' quantities and expenditure of commodities consumed. The price for trout, organic and conventional salmon used in this study is the weighted average expressed in DKK/Kg. These retail level prices are weekly observations and spans from 2013 week 40 to 2015 week 52.

Figure 2 presents price development over time for the retail and farm level prices respectively. As can be seen in the left figure, the price of conventional trout is always lower

2 See results section for the kind of restrictions imposed on the cointegrating vectors. 
than salmon prices. The organic salmon price is the most valued. The average percent difference in price between organic and conventional salmon is more than 50 percent. Ankamah-Yeboah et al. (2016) show using data for 2013 and 2014, and controlling for other salmon attributes that the premium for organic salmon range from 20 to 36 percent. While a stable price is observed for the conventional salmon and trout prices, the organic salmon prices tend to be more volatile.

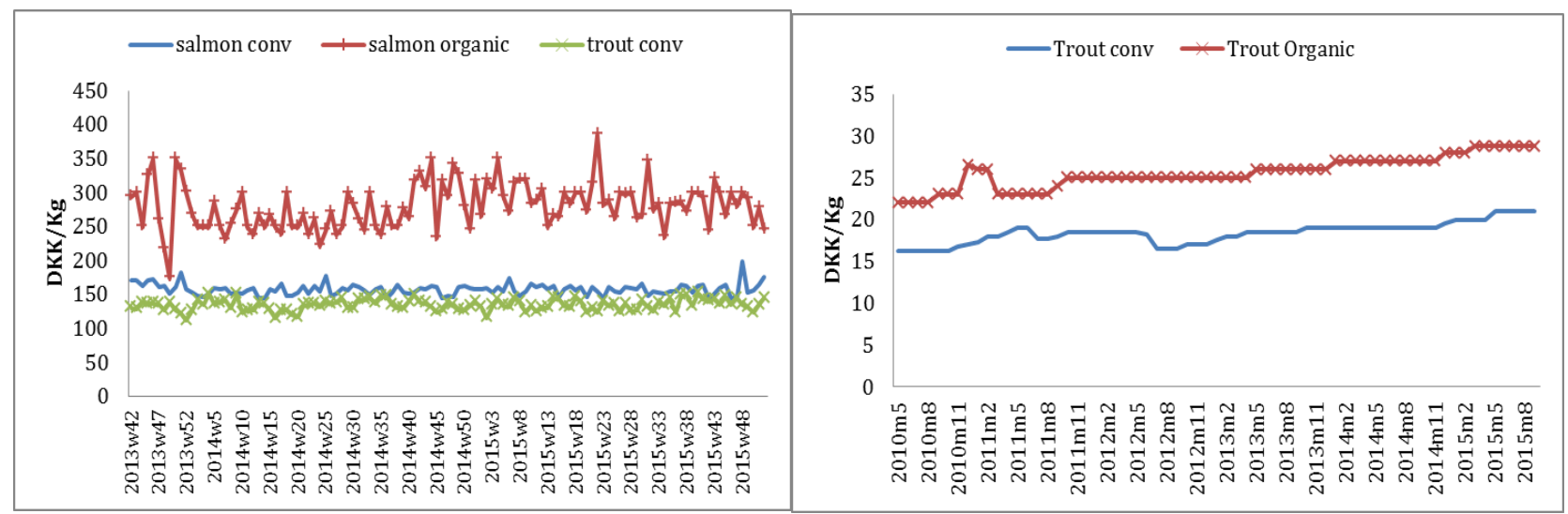

Figure 2 a) Weekly retail salmon and trout prices b) Monthly farm level trout prices

The farm level trout in the right figure shows that the organic and conventional trout prices show similar patterns. The difference in prices which indicates the premium is estimated to be around 33 percent. The stability of prices over several months might be a reflection of fixed contract pricing and revisions. For the subsequent analyses, all variables are expressed in logarithms. Table 3 below shows the summary of prices used in the analysis. Generally trout prices are lower relative to salmon and farm levels are also the lowest as expected. The organic prices are higher than the conventional salmonids price.

Table 3 Summary Statistics of Prices in DKK

\begin{tabular}{lrrrrr}
\hline & $\begin{array}{l}\text { Farm Level } \\
\text { Conv. } \\
\text { Trout }\end{array}$ & \multicolumn{1}{l}{$\begin{array}{l}\text { Organic } \\
\text { Trout }\end{array}$} & $\begin{array}{l}\text { Retail Level } \\
\text { Conv. } \\
\text { Salmon }\end{array}$ & \multicolumn{1}{l}{$\begin{array}{l}\text { Organic } \\
\text { Salmon }\end{array}$} & \multicolumn{1}{c}{$\begin{array}{l}\text { Conv. } \\
\text { Trout }\end{array}$} \\
\hline Mean & 18.40 & 25.58 & 157.59 & 280.21 & 134.30 \\
Median & 18.50 & 25.00 & 157.44 & 279.75 & 134.34 \\
Maximum & 21.00 & 28.75 & 198.52 & 385.27 & 151.88 \\
Minimum & 16.25 & 22.00 & 142.58 & 175.00 & 112.02 \\
Standard & & & & & \\
Deviation & 1.28 & 1.91 & 8.47 & 33.69 & 8.24 \\
\hline
\end{tabular}

\section{Results}

As indicated earlier, analysis of price relationships within market integration concept depends on whether the price series have unit root process. In table 4 the unit root tests are 
presented. For the ADF test, we specify models with and without constant and trend terms. Using combinations of information criteria, the null hypothesis of unit root is tested in level and first difference. Failing to reject the null hypothesis in level and rejecting in first difference indicates that the series has unit root. The ADF statistics shown in Table 4 indicates that organic and conventional salmonids in both nodes of the value chain have unit root for all the three specifications. For retail conventional trout and salmon, unit root is revealed only at the ADF specification without constant and trend. The constant and trend specifications indicate a stationary processes.

Since it is evident that all variables have unit root with the specification without constant and trend, we proceed with the cointegration test.

Table 4 Unit Root Test

\begin{tabular}{llllll}
\hline & Farm Level & \multicolumn{3}{l}{ Retail Level } \\
\hline Market & $\begin{array}{l}\text { Organic } \\
\text { Trout }\end{array}$ & $\begin{array}{l}\text { Conventional } \\
\text { Trout }\end{array}$ & $\begin{array}{l}\text { Organic } \\
\text { Salmon }\end{array}$ & $\begin{array}{l}\text { Conventional } \\
\text { Trout }\end{array}$ & $\begin{array}{l}\text { Conventional } \\
\text { Salmon }\end{array}$ \\
\hline Level ADF & & & & & \\
None & $1.516^{\text {aic }}$ & $1.215^{\text {sic }}$ & -0.089 & $-0.029^{\text {maic }}$ & $-0.060^{\text {maic }}$ \\
Constant & $-1.073^{\text {aic }}$ & $-1.695^{\text {sic }}$ & -1.552 & $-3.540^{* * * \text { maic }}$ & $-9.911^{* * * \text { maic }}$ \\
Constant and Trend & $-1.959^{\text {aic }}$ & $-2.935^{\text {aic }}$ & -2.001 & $-3.775^{* * \text { maic }}$ & $-9.851^{* * * \text { maic }}$ \\
First $\Delta-A D F$ & & & & & \\
None & $-6.524^{* * *}$ & $-8.040^{* * *}$ & $-15.948^{* * *}$ & $-15.770^{* * *}$ & $-16.518^{* * *}$ \\
Constant & $-6.683^{* * *}$ & $-8.185^{* * *}$ & $-15.879^{* * *}$ & $-15.702^{* * *}$ & $-16.444^{* * *}$ \\
Constant and Trend & $-6.628^{* * *}$ & $-9.844^{* * * a i c}$ & $-15.807^{* * *}$ & $-15.631^{* * *}$ & $-16.410^{* * *}$ \\
\hline
\end{tabular}

Lags automatically selected using Schwarz's and (modified) Akaike's information criteria (aic, sic and maic). ${ }^{* * *}$ and ${ }^{* *}$ indicate significance at $1 \%$ and $5 \%$ significance level respectively

The results presented in Table 5 are the cointegration test using the Johansen maximum likelihood approach. The cointegration test involves a simultaneous determination of the evidence of cointegration at the rank of $n-1$ and the estimation of a well-defined error correction model. Specifications considered include 1) no trend 2) restricted constant and 3) unrestricted constant, with seasonal dummies and the number of lags that makes the residuals white noise. For all models estimated, the portmanteau test for serial correlation (indicated by Q-stat) and the vector residual heteroscedasticity test shown at the bottom of Table 5 indicate that the models are well specified. The farm level model however, fails on normality test of residuals. The consequence is absorbed by the robustness of the Johansen's trace and maximum eigenvalue test for cointegration to non-normal errors (Cheung and Lai, 1993 and Gonzalo, 1994).

First considering the farm level salmonids market, the null hypothesis of no cointegration which is a test of $r=0$ is significantly rejected at the 5 percent level. A rank of $r=1$ is however not rejected. This evidence is also consistent in both the trace $\left(\lambda_{\text {trace }}\right)$ and maximum eigenvalue $\left(\lambda_{\max }\right)$ statistics. The VAR specification is modelled with a restricted constant using two lags. This show evidence that that farm level organic and conventional trout have a long run relationship (i.e., cointegrated). With a rank of one, we are able to effectively conclude that the two markets are integrated and function in the same market. 
Though it is possible that farm level organic and conventional trout prices may vary in the short run, stability of price premium is maintained in the long run across the different production methods.

The cointegrating vector is estimated to be positive and close to one $(\beta=1.097)$, indicating they have a very close relationship between them. A likelihood ratio test of the "Law of One Price"; $\beta^{\prime}=\left(\begin{array}{ll}1 & -1\end{array}\right)$ produces LR statistic of 0.16 that fails to be rejected at any significance level. This implies that the LOP holds and that the prices are proportional to each other. A likelihood ratio test on the speed of adjustment parameter $\alpha$ indicates insignificant $\alpha_{1}$ and a statistically insignificant $\alpha_{2}$. This shows that the farm level conventional trout which corresponds to $\alpha_{1}$ is weakly exogenous and as such acts as the market leader in determining market prices. Alternatively, the organic trout prices acts as the market follower. A simple conclusion is that the organic trout price is essentially determined on the large market for conventional trout in the long run.

Table 5 Cointegration, Proportionality and Weak Exogeneity Tests

\begin{tabular}{|c|c|c|c|}
\hline Farm Level & & Retail Level & \\
\hline & $\begin{array}{l}\text { Conv. Trout/ } \\
\text { Organic Trout }\end{array}$ & & $\begin{array}{l}\text { Conv. Salmon/ } \\
\text { Organic Salmon/ } \\
\text { Conv. Trout }\end{array}$ \\
\hline Model(Lags) & $2 \mathrm{M}(2)$ & Model(Lags) & $1 \mathrm{M}(2)$ \\
\hline$\lambda_{\text {trace }}-$ Statistic & & $\lambda_{\text {trace }}-$ Statistic & \\
\hline$r=0$ & $22.261^{* *}$ & $r=0$ & $77.657^{* * *}$ \\
\hline$r=1$ & 4.044 & $r=1$ & $25.107^{* * *}$ \\
\hline$r=2$ & - & $r=2$ & 0.201 \\
\hline$\lambda_{\max }-$ Statistic & & $\lambda_{\max }-$ Statistic & \\
\hline$r=0$ & $18.555^{* *}$ & $r=0$ & $52.551^{* * *}$ \\
\hline$r=1$ & 4.044 & $r=1$ & $24.905^{* * *}$ \\
\hline$r=2$ & - & $r=2$ & 0.201 \\
\hline$\beta$ & 1.097 & {$\left[\beta_{13}\right]$ and $\left[\beta_{23}\right]$} & -1.115 and -0.970 \\
\hline LR-Stat of $(\beta=1)$ & 0.160 & $\begin{array}{l}\text { LR-Stat of } \\
{\left[\beta_{13}=1\right] \text { and }\left[\beta_{23}=1\right]}\end{array}$ & $19.786^{* * *}$ \\
\hline $\begin{array}{c}\text { Weak Exogeneity } \\
\alpha_{1}\end{array}$ & -0.020 & $\begin{array}{l}\text { Weak Exogeneity } \\
{\left[\alpha_{11}, \alpha_{12}\right] \text { and }} \\
\text { LR test }\left[\alpha_{11}=\alpha_{12}=0\right]\end{array}$ & $\begin{array}{l}{[-0.692][0.428]} \\
23.645^{* * *}\end{array}$ \\
\hline$\alpha_{2}$ & $0.200^{* * *}$ & $\begin{array}{l}{\left[\alpha_{21}, \alpha_{22}\right] \text { and }} \\
\operatorname{LR} \text { test }\left[\alpha_{21}=\alpha_{22}=0\right] \\
{\left[\alpha_{31}, \alpha_{32}\right] \text { and }} \\
\text { LR test }\left[\alpha_{31}=\alpha_{32}=0\right]\end{array}$ & $\begin{array}{l}{[0.030][-0.587]} \\
23.267^{* * *} \\
{[0.090][0.526]} \\
26.358^{* * *}\end{array}$ \\
\hline Misspecification tests & & & \\
\hline Q-Stat(Lags=3) & $3.624(0.805)$ & Q-Stat(Lags=3) & $14.060(0.277)$ \\
\hline P (VEC res. Hetero.) & 0.056 & P (VEC res. Hetero.) & 0.088 \\
\hline
\end{tabular}


the trace and maximum eigenvalue statistic. Again we effectively conclude evidence of market integration given the rank of two (i.e., two cointegrating equations) in the trivariate system. The cointegrating vectors for the two cointegrating equations are estimated to be close to unity, however, a test of the LOP; thus $\beta^{\prime}=\left(\begin{array}{lll}1 & 0 & -1 \\ 0 & 1 & -1\end{array}\right)$ shown in Table 5 as $\left[\beta_{13}=1\right]$ and $\left[\beta_{23}=1\right]$ is rejected at the $1 \%$ significance level using LR test. Hence a partially integrated market is found between commodities at the retail level. This implies that in the event of a shock, organic prices can be sold as conventional prices, but not below.

Weak exogeneity of prices and the determination of feedback from the respective retail markets are tested by the joint significance of $\alpha_{i j}=\alpha_{i k}=0, \forall j \neq k$, under the restrictions of the estimated cointegrating vectors. As shown in Table 5, the LR statistic is rejected at the 1 percent significance level for all the three variables indicating that there are feed-back effects or adjustment back to equilibrium following deviant price behaviors between the salmonids market.

In order to affirm the findings of cointegration, it is necessary to ensure that price series are nonstationary. Price series are thus tested for stationarity using the post-estimation approach by imposing the following restrictions on the bivariate case with rank 1 : ( $i) \beta^{\prime}=\left(\begin{array}{ll}1 & 0\end{array}\right)$ and $(i i) \beta^{\prime}=\left(\begin{array}{ll}0 & 1\end{array}\right)$ for a bivariate system with rank of one. The respective restrictions produce likelihood ration statistic of 4.66 and 6.92 with $5 \%$ and $1 \%$ levels of significance. For a trivariate system with rank of 2 , the following restrictions $\beta^{\prime}=\left(\begin{array}{lll}1 & 0 & 0 \\ 0 & 1 & 0\end{array}\right)$, $\beta^{\prime}=\left(\begin{array}{lll}1 & 0 & 0 \\ 0 & 0 & 1\end{array}\right)$ and $\beta^{\prime}=\left(\begin{array}{lll}0 & 1 & 0 \\ 0 & 0 & 1\end{array}\right)$ are imposed. The respective likelihood ratio statistics are $24.65,48.12$ and 46.51 , all significant at the $1 \%$ level. These restrictions are a test of the null hypothesis of a stationary process. Hence the conclusion is that the cointegration relationships are driven by unit root processes.

The IRFs are presented in Figures 4 and 5 for cross market shocks. The IRFs show how a shock to one particular variable is reverberated in the system over time. The IRFs are based on the Cholesky decomposition of the contemporaneous covariance matrix. Thus, the variables appearing first in the VAR model have contemporaneous impacts while the later have lag impacts. Hence, we order as: organic and conventional trout for the farm level; and conventional salmon, organic salmon and conventional trout for the retail level model. The bootstrap method with 90 percent confidence interval for the responses was used with a VAR residual sampling of 999 replications. Validity of the IRF depends on stability of the model. For a VEC specification with $r$ cointegrating relations, $n-r$ roots should be equal to unity for stability condition to hold (Juselius, 2006). The IRF was estimated by ensuring that in each model one real root lies on the unit circle of the characteristic polynomial.

As shown in Figure 4, a shock in the farm level organic trout leads to a permanent increase in the conventional trout (see panel A). This increase in the conventional trout prices however, takes effect following the fifth month. A shock to the conventional trout prices on the other hand has no effect on the organic trout prices in the short run, as shown in panel B. 
The IRFs for the retail level prices shown in Figure 5, indicate that a shock to organic salmon prices resonates the conventional retail trout prices for the first two weeks but a permanent and stable increase from the third week (see panel A). The conventional salmon price as well starts increasing from the third week and reaches a stable and permanent increase from the sixth week (see panel B). A shock to the conventional retail trout only increases organic salmon prices in the third week, but falls back to the previous level in the next period (see panel C); and permanently increases the conventional salmon prices from the second week and maintains stability from the seventh week (see panel D). As shown in panels $\mathrm{E}$ and $\mathrm{F}$ respectively, a shock to the conventional salmon prices causes no effect on the organic salmon prices, but a permanent increase in the conventional trout prices.

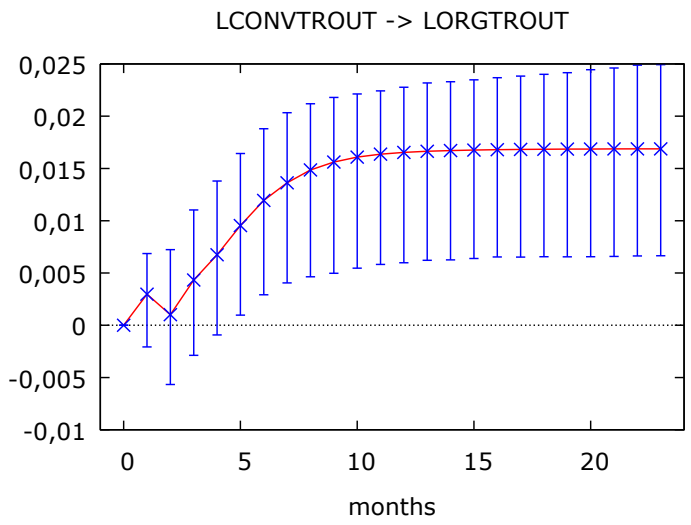

Panel A
LORGTROUT -> LCONVTROUT

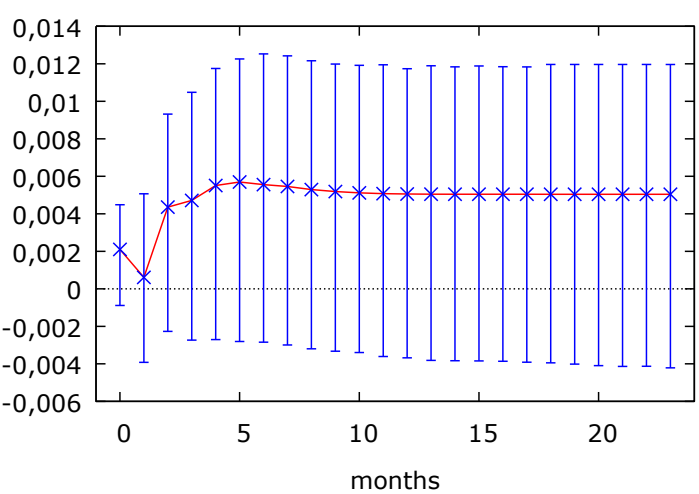

Panel B

Figure $4 \quad$ Farm level - impulse responses of one standard error shock 


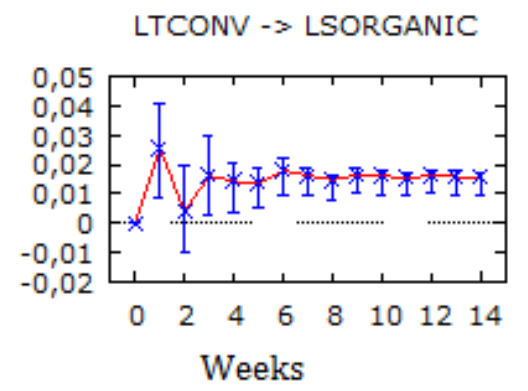

Panel A

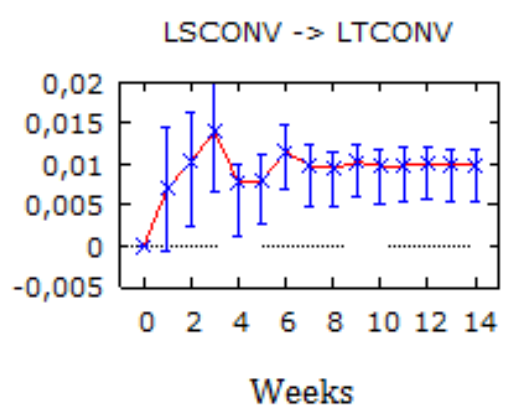

Panel D

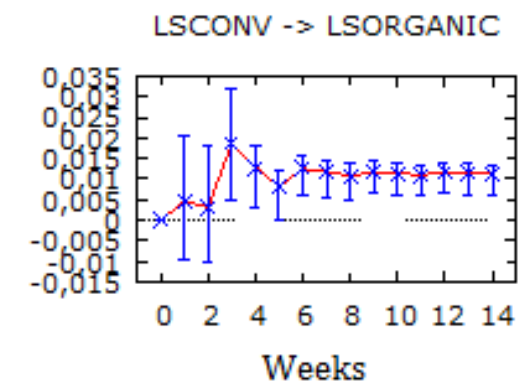

Panel B

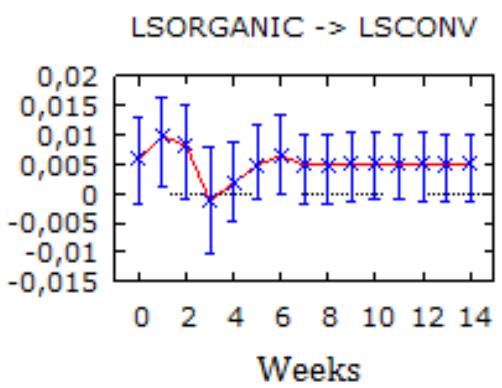

Panel E

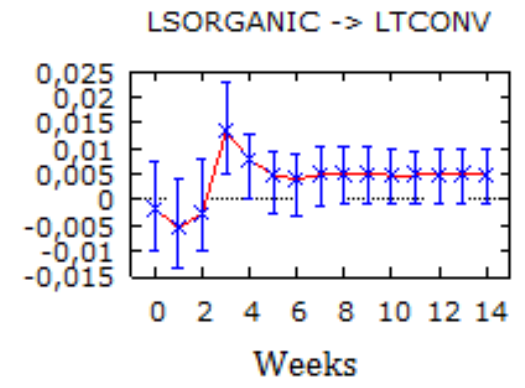

Panel C

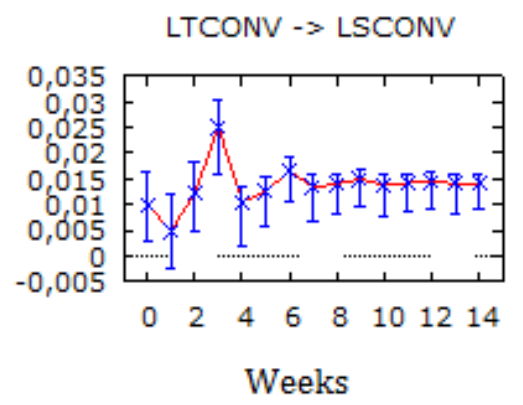

Panel F

Figure 5 Retail level - impulse responses of one standard error shock

In summary, the study identifies price relations between organic and conventional salmonids in the long and short run. Results in the long run indicate that for the farm level trout markets, there exist a stable price premia between the conventional and organic trout markets, given that the LOP or constant relative prices is estimated in the presence of cointegration. Further, the organic trout prices are found to be determined by the conventional trout prices at the farm level. The adjustment time horizon reveals that in the short run, a shock to the organic trout prices will cause a permanent increase in the conventional trout prices from the fifth month, while maintaining the constant relative prices (constant premium), but not vice versa.

At the retail level, the long run analysis indicates that while organic and conventional markets are integrated, the test of constant relative prices between the organic and conventional salmonids does not hold. Price premia will vary, but randomly and with each market contributing in the determination of the price of the other in the market. In the short run however, a shock to the organic salmon prices cause a permanent increase in both the conventional salmon and conventional trout retail prices with the response starting in the third week. A corresponding shock to the conventional salmonids eventually leads to no response from the organic salmon market.

\section{Conclusion}


Market integration tests of non-stationary price series between organic/conventional products have been suggested as a pre-test to reduce investment risks for organic farming. The tests have also been applied to Danish salmonid markets. Upstream, market integration is identified between organic and conventional trout. The LOP holds and markets are perfectly integrated. Conventional trout is found to be market leader and impulse-response analysis identify significant short run effects from organic to conventional trout prices after 5 months, but with insignificant results vice versa.

Downstream, markets for organic salmon, conventional trout and conventional salmon is identified as integrated, while LOP and market leaders was not found. Impulse-response analysis show significant short run effects from organic to conventional salmonid prices already after 3 weeks, but with tests in the opposite direction being insignificant. This result is surprising. While the reasons remain a matter of speculation, it might be that buyers of the expensive organic products react faster to shocks than buyers of conventional goods, but that need to be confirmed in further enquiry. Organic and conventional prices also adjust faster downstream than upstream. While price premiums exist downstream, market integration is not perfect, but nevertheless exists and forms the basis for a price premium that can be transmitted upstream.

On this basis, it is concluded that investment in organic trout farming can be made in Denmark without risking of a reduced price premium. Ceteris paribus, growth in organic salmonids will not reduce price premiums given the small share of organic trout upstream and organic salmonids downstream.

The method is broadly applicable to identify stable price premiums and, thereby, to reduce investment risks when the organic market share is small and organic supply grow. Only the risk associated with organic supply growth is identified and the risk associated with supply and demand developments at the total market still remain.

The results are obtained for a small dataset and the reliability can be increased with more data. However, availability of few data is the rule rather than the exception at emerging markets including organic salmonids in Denmark and the indications of a stable price premium is important knowledge when an investment decision is made.

\section{Reference}

Anderson, J.L. (2002). Aquaculture and the future: Why fisheries economist should care. Marine Resource Economics 17, 133-151.

Ankamah-Yeboah, I., L. Staahl and M. Nielsen, Market integration of cold- and warm-water shrimp in Europe, forthcoming in Marine Resource Economics.

Ankamah-Yeboah, I., M. Nielsen and R. Nielsen (2016), Price premium of organic salmon in Danish retail sale, Ecological Economics 122:54-60. 
Ankamah-Yeboah, I., Nielsen, M. and Nielsen, R. (2016) Price Premium of Organic Salmon in Danish Retail Sale. Ecological Economics 122, 54-60.

Asche, F. (2008). Farming the sea. Marine Resource Economics 23, 507-527.

Asche, F., Bjørndal, T. (2011). The Economics of Salmon Aquaculture, Second edition. WileyBlackwell.

Asche, F., Bremnes, H. and Wessells, C. R. (1999), Product Aggregation, Market Integration and the Relationships between Prices: An Application to World Salmon Markets, American Journal of Agricultural Economics, 81:568-81.

Asche, F., Bremnes, H., \& Wessells, C. R. (2001). Product aggregation, market integration, and relationships between prices: An application to world salmon markets: Reply. American Journal of Agricultural Economics, 83(4), 1090-1092.

Asche, F., Gordon, D. V., \& Hannesson, R. (2004). Tests for market integration and the law of one price: the market for whitefish in France. Marine Resource Economics, 195-210.

Asche, F., Guttormsen, A.G. and Nielsen, R. (2013) Future challenges for the maturing Norwegian salmon aquaculture: An analysis of total factor productivity change from 1996 to 2008. Aquaculture 396-399, 43-50.

Asche, F., Larsen, T.A., Smith, M.D., Sogn-Grundvåg, G., Young, J.A. (2015). Pricing of ecolabels with retailer heterogeneity. Food Policy 53, 82-93.

Bronmann, J., I. Ankamah-Yeboah and M. Nielsen (2016), Market integration of pangasius and tilapia in relation to wild-caught whitefish in Germany, Marine Resource Economics 31(4):421-32.

Brunsø, K., Hansen, K.B., Scholderer, J., Honkanen, P., Olsen, S.O., Verbeke,W., Børresen, T. (2008). Consumer attitudes and seafood consumption in Europe. Improving Seafood Products for the Consumer, pp. 16-39.

Cheung, Y. W., \& Lai, K. S. (1993). Finite-sample sizes of Johansen's likelihood ratio tests for cointegration. Oxford Bulletin of Economics and statistics, 55(3), 313-328.

Christensen, T., Olsen, S.B., Kærgård, N., Dubgaard, A. (2014). Questionnaire on organic consumption. Frederiksberg: Institute for Food and Resource Economics. Copenhagen University, (IFRO Dokumentation; Nr. 2014/3) - In Danish.

Connolly, C., \& Klaiber, A. H. (2014). Does Organic Command a Premium When the Food is Already Local? American Journal of Agricultural Economics, 96(4), 1102-1116.

Corsi, A. and S. Strøm (2013), The Price Premium for Organic Wines: Estimating a Hedonic Farm-Gate Price Equation, Journal of Wine Economics 8(1):29-48.

Daviglus, M., Sheeshka, J., Murkin, E. (2002). Health benefits from eating fish. Comments Toxicol. 8 (4-6), 345-374.

Dickey, D. A., \& Fuller, W. A. (1979). Distribution of the estimators for autoregressive time series with a unit root. Journal of the American statistical association, 74(366a), 427-431.

Engle, R. F., \& Granger, C. W. (1987). Co-integration and error correction: representation, estimation, and testing. Econometrica: journal of the Econometric Society, 251-276.

FAO 2016 - Fisheries and Aquaculture Information and Statistics Branch - 13/12/2016 
Gonzalo, J. (1994). Five alternative methods of estimating long-run equilibrium relationships. Journal of econometrics, 60(1), 203-233.

Granger, C. W. J. \& Newbold, P. (1974). Spurious regressions in econometrics, Journal of Econometrics 2: 111-120.

Hessel, V. (1993). Dansk ørrederhverv gennem 100 år, Skellerup, Aarhus, Denmark

Hjalmarsson, E., \& Österholm, P. (2010). Testing for cointegration using the Johansen methodology when variables are near-integrated: size distortions and partial remedies. Empirical Economics, 39(1), 51-76.

Jacobi, S.L. (1765) Hannoversche Magazin, August 1765.

Johansen, S. (1988). Statistical analysis of cointegration vectors. Journal of economic dynamics and control, 12(2), 231-254.

Juselius, K. (2006). The cointegrated VAR model: methodology and applications. Oxford University Press.

Lutkepohl, H. (2005). New introduction to multiple time series analysis. Econometric theory, 22(5), 961-967.

Maguire, K.B., N. Owens and N. B. Simon (2004), The Price Premium for Organic Babyfood: A Hedonic Analysis, Journal of Agricultural and Resource Economics 29(1):132-149.

Meas, T., Hu, W., Batte, M. T., Woods, T. A., \& Ernst, S. (2015). Substitutes or Complements? Consumer Preference for Local and Organic Food Attributes. American Journal of Agricultural Economics, 97(4), 1044-1071.

Nielsen, M., Setälä, J., Laitinen, J., Saarni, K., Virtanen, J., \& Honkanen, A. (2007). Market integration of farmed trout in Germany. Marine Resource Economics, 22(2), 195213.Nielsen,

Nielsen, R., Andersen, J.L. and Bogetoft, P. (2014) Dynamic Reallocation of Marketable Nitrogen Emission Permits in Danish Freshwater Aquaculture. Marine Resource Economics 29, 219-239.

R. (2012) Introducing individual transferable quotas on nitrogen in Danish fresh water aquaculture: Production and profitability gains. Ecological Economics 75, 83-90.

Roheim, C.A., F. Asche and J.I. Santos (2011), The Elusive Price Premium for Ecolabelled Products: Evidence from Seafood in the UK Market, Journal of Agricultural Economics 62(3):655-668.

Schollenberg, L. (2012), Estimating the hedonic price for Fair Trade coffee in Sweden, British Food Journal 114(3):428-446.

Singerman, A., S. H. Lence and A. Kimble-Evans (2014), How Related Are the Prices of Organic and Conventional Corn and Soybean? Agribusiness 30(3):309-330.

Smith, T.A., C.L. Huang and B.H. Lin (2009), Estimating organic premiums in the US fluid milk market, Renewable Agriculture and Food Systems 24(3):197-204.

Statistics Denmark (2012) Detail sales after branches, commodities and type. Danmarks Statistik, www.statistikbanken.dk/DETA2012

Statistics Denmark (2016a) Detail sales of organic food products in volume and value. Danmarks Statistik, www.statistikbanken.dk/OEKO3 
Statistics Denmark (2016b) European consumer purchasing power - price comparisons, food and beverage 2015, prices and consumption. News from Statistics Denmark, 24. June 2016, Nr. 286.

Van Loo, E.J., V. Caputo, R. M. Nayga, J.F. Meullenet and S.C. Ricke (2011), Consumers' willingness to pay for organic chicken breast: Evidence from choice experiment, Food Quality and Preference 22:603-613

Würriehausen, N., R. Ihle and S. Lakner (2015), Price relationships between qualitatively differentiated agricultural products: organic and conventional wheat in Germany, Agricultural Economics 46:195-209. 